\title{
Comparison of methods for evaluating stability and maturity of co-composting of municipal solid wastes and sewage sludge in semi-arid pedo-climatic condition
}

\author{
Olfa Fourti*, Naceur Jedidi, Abdennaceur Hassen
}

Centre des Recherches et des Technologies des Eaux, Laboratoire Traitement et Recyclage, Cité Mahrajène, Tunisie; *Corresponding Author: olfa_fourti@yahoo.fr

Received 28 October 2010; revised 29 November 2010; accepted 3 December 2010.

\section{ABSTRACT}

The step of maturation (around 60 days) appeared less active as compared to the first step of pre-fermentation (around 90 days) since the values of temperature, recorded during the second step of maturation, are found generally less important than those recorded during the first step. A similar tendency of $\mathrm{C} / \mathrm{N}$ ratio values decrease is generally observed in the two piles of wastes during the two steps of composting and these $\mathrm{C} / \mathrm{N}$ ratio values determined in the pile of wastes free of sewage sludge (W1) are generally slightly higher than those observed in the pile added with dry sewage sludge (W2). The amount of total heavy metals (order of content: $\mathrm{Zn}>\mathrm{Pb}>\mathrm{Ni}>\mathrm{Cu}>\mathrm{Cr}>\mathrm{Cd}$ ) appeared very heterogeneous and showed a large variation in the two piles of wastes. The use of sewage sludge in the pile W2 showed generally no apparent impact on the whole amount of total heavy metals recorded in the finished product and the values recorded are usually lower than the metal concentration limits imposed by several countries. Microbial inventory and total DNA extracted from composting materials followed during all the two steps of composting showed a net variation over time, and revealed specifically a good parallel progress according to the ambient temperature recorded inside the waste materials. It appeared also from this study that the microbial diversity is much nuanced in the case of windrow W2 added with sewage sludge as compared to that observed in the case of windrow W1 free of sewage sludge.

Keywords: Temperature; Compost; Heavy Metals; Microbial Diversity; Microbial DNA Concentration

\section{INTRODUCTION}

Composting is defined as a process of aerobic thermophilus microbial degradation or an exothermic biological oxidation of various organic wastes (sewage sludge, animal manures, yard waste, crop residues, municipal solid waste, fish scraps and mortality, and food waste and food process wastes) by many populations of the indigenous microorganisms which lead to a stabilized, mature, deodorized, hygienic product, rich in humic substances, easy to store and marketable as organic amendment or manure [1].

Composting aimed to reduce the volume of wastes going to the landfills and to facilitate recycling of nutrients in the organic wastes as a useful method of producing a stabilized product that can be used as a source of nutrients and soil conditioner in the field. The composted product has the advantage of improving soil structure, increasing soil organic matter, suppressing soil-borne plant pathogens and enhancing plant growth. Immature composts may contain more growth inhibiting substances than mature composts. Some of these growth inhibiting compounds include salts, free ammonia, phenolic substances, heavy metals, and organic acids.

For optimum aerobic composting, moisture is necessary to support the metabolic processes of microorganisms. Composting materials should be maintained within a range of 40 to $65 \%$ moisture. A higher percentage will increase anaerobic decomposition, while lower moisture content will slow down the composting process as microorganisms die or become dormant. Microbial diversity and activity during the composting process, mediating stabilization of organic wastes, is an important factor and key to consider in composting. A large variety of mesophilic, thermotolerant and thermophilic aerobic microorganisms (including bacteria, actinobacteria, yeast, moulds and various other fungi) have been extensively reported in composting and other self-heating organic materials at temperatures between 20 and $60^{\circ} \mathrm{C}[2,3]$. 
Many factors determine the microbial communities during composting. Under aerobic conditions, temperature is a major factor determining the type of microorganisms, species diversity, and the rate of metabolic activities [3]. On the other side, waste stream from biosolids or municipal solid waste can contain elevated concentration of various metals as potential toxic elements (PTEs), and the impact of metals on compost quality and use is a major concern throughout the world [4]. In small amounts, many of these elements may be essential for plant growth; however, in higher concentrations they are likely to have a detrimental effect upon plant growth.

A molecular detection procedure, using ribosomal intergenic spacer analysis, was tested for microbial community diversity assessment. Analysis of compost microbial communities is one of the challenging areas of research due to the enormous complexity of biodiversity caused by the heterogeneity of the physical and chemical structure of compost environments. Recently, a number of molecular biological methodologies have been successfully developed and introduced to reveal the biodiversity of microbial communities in a wide range of environments including soils [5,6] and solid wastes [7-9]. This diversity concerned pathogens and saprophytic microorganisms useful for a good procedure and organization of the composting process.

The aim of this study was to assess, in a semi-industrial pilot plant and under semi-arid pedo-climatic conditions, a new process of co-composting of municipal solid wastes and sewage sludge. So, some physico-chemical, biochemical and microbiological parameters are followed during the two steps of pre-fermentation (uncontrolled fermentation) and of maturation (controlled fermentation), respectively. Also, total heavy metals content as potential toxic elements (PTEs) and microbial diversity are evaluated.

\section{MATERIALS AND METHODS}

Preparation and monitoring of windrows. The study was performed in a semi-industrial pilot plant and using two types of windrow W1 and W2. The process of composting proceeds in two successive separately steps: pre-fermentation (uncontrolled fermentation) and maturation (controlled fermentation), and with two different raw composting materials: municipal solid waste from the Erriadh city of Beja were pre-selected at source (household pre-selection with average physical-chemical characteristics, humidity $=60 \%$, organic matter $=30 \%$ dry weight, and $\mathrm{C} / \mathrm{N}=32$ ) and dry sewage sludge (stabilized from anaerobic digestion of the urban wastewater treatment plant of Beja was integrated in the process at the dry state (with average physical-chemical characteristics, humidity $=30 \%$, organic matter $=65 \%$ dry weight, and $\mathrm{C} / \mathrm{N}=12.5$ ) and primarily for the cover of windrow W2. During the first step, the two windrows W1 and W2 of pyramidal form (of approximately $7 \times 3 \times 1.5 \mathrm{~m}^{3}$, length $\times$ width $\times$ height, respectively) are constituted exclusively with raw waste materials $(100 \%$ of municipal solid wastes) for $\mathrm{W} 1$ and $(60 \%$ of municipal solid wastes and a superficial layer of dry sewage sludge of about $40 \%$ of dried sewage sludge) for $\mathrm{W} 2$, respectively, and deposed in the platform of composting, under natural conditions, for 3 months of pre-fermentation. Secondly, at the end of this period of pre-fermentation, the waste material of each windrow is submitted to a deep manual sorting and fermentable organic material is chipped, shred, sieved to $40-\mathrm{mm}$ stitch sieve to reduce heterogeneity and subjected for approximately 2 months to a second controlled fermentation in pile of about 1.5 $\mathrm{m}$ of height. The pile of wastes during the first step of process is left under natural condition without any maintenance, and on the contrary the maintaining of waste pile during the second step of composting consists to monitor temperature inside the pile in order to maintain a temperature around $25-55^{\circ} \mathrm{C}$, by turning as needed (1-3 times per month), and to preserve pile moisture at the consistency of a well-wrung sponge by watering. The finished product is sieved with a $10-\mathrm{mm}$ stitch sieve.

Temperature and humidity were controlled daily. When the mean temperature recorded in the different depths (depths 20, 40 and $60 \mathrm{~cm}$ ) of the pile averaged $55^{\circ} \mathrm{C}$ (using a thermo-couple iron-constantan type J), the windrow was turned and watered. These operations of turning and watering with tap water were performed almost twice monthly in considering ambient temperature.

Temperature inside the pile is regularly determined (at least 1 time per week) at many different places and at two different depths of 20 and $100 \mathrm{~cm}$, using a thermocouple thermometer; iron-constantan type J and humidity (approximately $50 \mathrm{~g}$ of the waste sample was dried at $105^{\circ} \mathrm{C}$ in an oven for $24 \mathrm{~h}$ ) is regularly controlled.

Analytical methods. Samples of wastes are in general taken every 2 weeks and sampled as described by [10]. These samples are subjected to different determinations after screening through $12 \mathrm{~mm}$ (0.5 inch) mesh.

Electrical conductivity (EC) and $\mathrm{pH}$ are measured in 10:50 (dry compost: deionized water) extracts using a standard pH-meter (LPH 230 T, Tacussel electronic, France) and a standard conductivity-meter (Orion research, model 150, USA).

Total nitrogen $(\mathrm{N})$ and total organic carbon (C) are determined by the Kjeldahl method [11] and by the wet dichromate oxidation method [12], respectively.

Organic matter is determined by ashing at $550^{\circ} \mathrm{C}$ for 2 $\mathrm{h}$ in a muffle furnace.

Total heavy metal contents are measured by an atomic 
absorption spectrophotometer (Perkin-Elmer, Model 560) after digestion of the samples in concentrated $\mathrm{HNO}_{3}$ $\mathrm{HClO}_{4}(2: 1)$ according to [13].

Biological parameters. Total indigenous viablecultivable mesophilic and thermophilic bacteria from different suspension-dilution of waste samples are enumerated by the pour plate technique on Tryptic soy agar (Pasteur Production, Paris). Enumerations are performed after 3 days of incubation at 28 and $55^{\circ} \mathrm{C}$ for mesophilic and thermophilic bacteria, respectively. The count of sporeforming bacteria includes several steps from selection by applying heat to destroy vegetative bacteria $\left(80^{\circ} \mathrm{C}\right.$ for 10 $\mathrm{min}$ ) to the indication by spreading volumes of the sample into Tryptic soy agar followed by incubation at $37^{\circ} \mathrm{C}$ for 3 days. Spore-counting bacteria were expressed as colony-forming units per gram (CFU s/g) of dry weight of compost.

The deshydrogenase activity expressed as triphenylformazan unit is measured according to Tabatabai [14].

Solid waste microbial biomasses $\mathrm{C}\left(\mathrm{B}_{\mathrm{C}}\right)$ and $\mathrm{N}\left(\mathrm{B}_{\mathrm{N}}\right)$ are evaluated using the Fumigation-Extraction method and total microbial DNA extraction method [15].

DNA was extracted and purified from equivalent dry weights of each waste materials sample $(500 \mathrm{mg}$ fresh materials), using the Bio 101 Fast DNA Kit for Soil (Biogene, France), according to the manufacturer instructions. Purified DNA was quantified by spectrophotometry (Bio-RAD Smart Spec ${ }^{\mathrm{TM}}$ Plus, France) [16]. The spectrophotometric A260/A280 and A260/A230 ratios were determined to evaluate levels of protein and humic acid impurities, respectively, in the extracted DNA [17]. These last methods recommended at first for soil microbial biomass analysis is used in this study for microbial biomass determination in the compost [18].

The microbial diversity in compost is evaluated by DNA extraction and polymerase chain reaction (PCR) of rRNA intergenic spacer. Total DNA extraction and purification are performed on waste extracts according to [5]. Each DNA sample was used as template to amplify the intergenic spacer between the genes encoding for the large (23S) and small (16S) subunits of ribosomic RNA. Universal eubacterial primers are used. Amplification products were resolved in a 5\% non-denaturing acrylamide gel, stained with SYBR green I and photographed under UV illumination.

Pearson's correlation coefficients between selected parameters were calculated.

\section{RESULTS AND DISCUSSION}

\subsection{Temperature Profiles}

Temperature profiles established during the two steps of composting (pre-fermentation and maturation) in the two windrows $\mathrm{W} 1$ and $\mathrm{W} 2$ revealed the three classical temperature steps of composting the mesophilic, thermophilic and cooling phases, respectively (Figure 1). The step of maturation (around 60 days) appeared less active as compared to the first step of pre-fermentation (around 90 days) since the values of temperature, recorded during the second step of maturation, are found generally less important than those recorded during the first step. Differences in temperature averaged $15^{\circ} \mathrm{C}$.

\subsection{Evolution of the Physico-Chemical Parameters of Composting}

\subsubsection{Acidity}

Ideally, the $\mathrm{pH}$ should be in the range of $6-8$ to allow the highest rates of decomposition. If the $\mathrm{pH}$ is outside this range, microbial activity will be compromised and decomposition will be slowed or even stopped. The $\mathrm{pH}$ values recorded in the two piles $\mathrm{W} 1$ and $\mathrm{W} 2$ showed in general a weak variation from the beginning until the end of pre-fermentation, and present a slight acidic compost increase during the step of maturation (Table 1).

\subsubsection{Conductivity}

The change in value of electrical conductivity (EC), used as chemical indicators and as an indirect measure of the soluble salts in a growing medium, for the two windrows may be due to the characteristics and the amounts of the materials used for constructing the pile of wastes. The electrical conductivity showed no major variation for the two windrows during the two steps of composting, and limit values averaged $60 \mathrm{~ms} / \mathrm{m}$ (Table 1). The addition of dry sewage sludge to windrow W2 seems have no apparent impact on the conductivity value of the compost.

\subsubsection{Organic Matter}

The degradation rate of organic matter during composting is importantly used to evaluate the compost maturity. The organic matter decreased notably over time during the first step of pre-fermentation in the two windrows W1 and W2, 20.9 to 13.5 and 20.44 to $13.60 \%$, respectively (Table 1), pointing to active degradation of the organic materials during this step. On the other side, organic matter degradation appeared no so active during the second step of maturation in the two windrows, 12.24 to 10.8 and 12.4 to $11.45 \%$, respectively.

\subsubsection{C/N Ratio}

At the beginning of the first step of pre-fermentation, the $\mathrm{C} / \mathrm{N}$ ratio values averaged 30 and these values decreased remarkably at the end of this step to 23.22 and 20.2 for windrows $\mathrm{W} 1$ and $\mathrm{W} 2$, respectively. These results, both valid for the two piles of wastes, indicate a 
Windrow 1
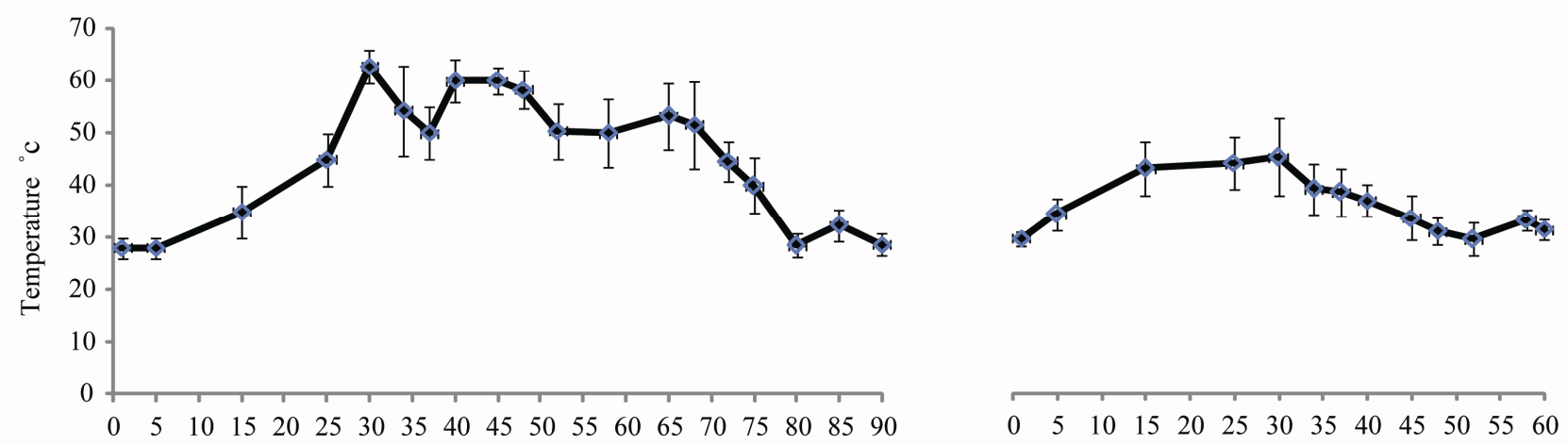

Windrow 2

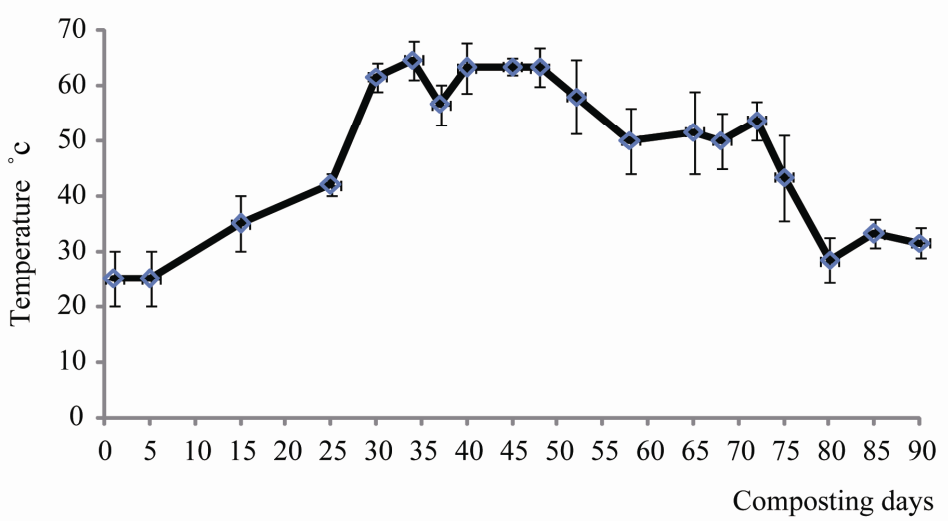

Step 1 of prefermentation
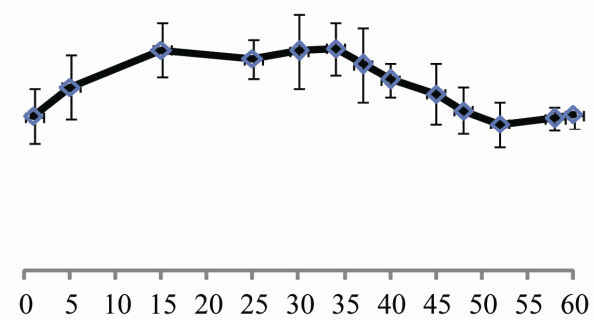

Step 2 of maturation

Figure 1. Progress of average temperature values in the two windrows during the two steps of composting.

Table 1. Limit values of the main physical-chemical parameters determined during the two steps of composting.

\begin{tabular}{|c|c|c|c|c|c|}
\hline & \multirow{2}{*}{ Parameters } & \multicolumn{2}{|c|}{ Step 1 of pre-fermentation } & \multicolumn{2}{|c|}{ Step 2 of maturation } \\
\hline & & Initial waste & Final waste & Precompost & Final compost \\
\hline \multirow{4}{*}{ W1 } & pH (water) & $7.07 \pm 0.30$ & $6.66 \pm 0.08$ & $7.02 \pm 0.2$ & $8.58 \pm 0.01$ \\
\hline & $\mathrm{EC}(\mathrm{ms} / \mathrm{m})$ & $62.08 \pm 26.80$ & $70.40 \pm 24.70$ & $75.24 \pm 16.54$ & $68.57 \pm 20.55$ \\
\hline & MO (\%) & $20.90 \pm 1.60$ & $13.50 \pm 1.02$ & $12.24 \pm 0.82$ & $10.80 \pm 0.80$ \\
\hline & $\mathrm{C} / \mathrm{N}$ & $32 \pm 3.2$ & $23.22 \pm 2.1$ & $22.2 \pm 1.6$ & $15.2 \pm 1.4$ \\
\hline \multirow{4}{*}{ W2 } & $\mathrm{pH}$ (water) & $6.56 \pm 0.12$ & $7.10 \pm 0.12$ & $7.20 \pm 0.08$ & $8.34 \pm 0.01$ \\
\hline & $\mathrm{EC}(\mathrm{ms} / \mathrm{m})$ & $58.01 \pm 14.44$ & $51.14 \pm 31.26$ & $73.39 \pm 15.85$ & $68.84 \pm 20.30$ \\
\hline & MO (\%) & $20.44 \pm 1.85$ & $13.60 \pm 1.66$ & $12.40 \pm 0.14$ & $11.45 \pm 0.78$ \\
\hline & $\mathrm{C} / \mathrm{N}$ & $28.72 \pm 2.9$ & $20.2 \pm 2.2$ & $21.4 \pm 1.2$ & $13.6 \pm 1.2$ \\
\hline
\end{tabular}

EC: Electrical conductivity. OM: Organic matter content. $\mathrm{C} / \mathrm{N}$ ratio. $\mathrm{n}=3 . \pm$ : Deviation standard. 
high rate of biological activities. The similar tendency of result is observed during the second step of maturation since there is a net decrease of $\mathrm{C} / \mathrm{N}$ ratio between the beginning and the end of this step of maturation, 22.2 to 15.2 and 21.4 to 13.6 in the two piles of wastes, respectively.

The $\mathrm{C} / \mathrm{N}$ ratio values determined in the pile of wastes free of sewage sludge (W1) are generally slightly higher than those observed in the pile added with dry sewage sludge (W2). This result is certainly due to the special composition of sewage sludge used (around 30\% of the total composting wastes) in the windrow W2. This substrate is therefore loaded in degradable carbon and compost must lead to a very steady and slowly biodegradable compound (low $\mathrm{C} / \mathrm{N}$ ).

\subsubsection{Heavy Metals}

Table 2 illustrates the total concentration of metals $(\mathrm{Zn}, \mathrm{Pb}, \mathrm{Cu}, \mathrm{Ni}, \mathrm{Cr}, \mathrm{Cd})$ during the two steps of composting. The amount of total metal appeared very heterogeneous and showed a large variation. This tendency is valid for the two piles of wastes, and could be explained by the high bio-physical-chemical complexity of this environment; since there will be a loss by leaching and a concentration of metals by adsorption. The order of total metal content in the composted material and final compost was $\mathrm{Zn}>\mathrm{Pb}>\mathrm{Ni}>\mathrm{Cu}>\mathrm{Cr}>\mathrm{Cd}$. The use of sewage sludge in the waste of pile W2 showed generally no apparent impact on the whole amount of total heavy metals recorded in the finished product (Table 2).

\subsubsection{Microbial Biomass}

$\mathrm{B}_{\mathrm{C}} / \mathrm{B}_{\mathrm{N}}$ ratio values showed usually a net increase during the thermophilic phase, 30-70 and 20-50 days, for the steps of pre-fermentation and maturation, respectively (Figure 2). The $\mathrm{B}_{\mathrm{C}} / \mathrm{B}_{\mathrm{N}}$ ratio values are on average around 4-6 and 3-4 during the first and second steps of composting, respectively.

\subsubsection{Deshydrogenase Activity}

The deshydrogenase activity generally showed a net increase between 20-70 and 15-35 days through the prefermentation and maturation steps, respectively. A good positive correlation is observed between the values of deshydrogenase and of temperature recorded $(\mathrm{r}=0.96, \mathrm{P}$ $=0.01$ ). These values of deshydrogenase activity fluctuated between 3.2-5.84 and 1.7-5.66 triphenylformazan (TPF)/g of waste dry weight during the step of prefermentation in the two windrows $\mathrm{W} 1$ and $\mathrm{W} 2$, respectively (Figure 2). By the same, these values varied between 3.6-4.9 and 1.96-3.22 TPF/g of waste dry weight during the step of maturation in the two windrows W1 and W2, respectively. So variation of the deshydrogenase activity appeared very narrow (around 1.2 TPF/g of waste dry weight on average for $\mathrm{W} 1$ and $\mathrm{W} 2$ ) during the second step of composting and indicated a certain degree of homogeneity of the waste materials used in this second step of maturation; and in the opposite, a high heterogeneity of the waste used during the first step of pre-fermentation since variation of deshydrogenase values recorded were relatively large (around 2.64 and $4 \mathrm{TPF} / \mathrm{g}$ of waste dry weight for $\mathrm{W} 1$ and $\mathrm{W} 2$, respectively).

On the other hand, this activity appeared slightly higher in the windrow free of sludge than in the one with sewage sludge.

\subsection{Biological Parameters of Composting}

\subsubsection{Total Viable-Cultivable Mesophilic, Thermophilic and Spore-Forming Bacteria}

The changes in main microbial population, total viablecultivable mesophilic, thermophilic and spore-forming bacteria, in the two piles of composting materials during the two steps of process are presented in Figure 3. The number of mesophilic microorganisms during the first step of pre-fermentation varied, and during the first weeks of this step the number of these microorganisms remained stable around $8.5 \mathrm{Ulog}_{10} \mathrm{CFUs} / \mathrm{g}$ of compost dry weight in the two windrows $\mathrm{W} 1$ and W2. The lowest level of mesophilic bacteria in compost materials was recorded between 65 and 75 days of pre-fermentation (around $5.5 \mathrm{Ulog}_{10} \mathrm{CFUs} / \mathrm{g}$ of compost dry weight). From that moment, the number of mesophilic bacteria began to increase and remained at the level of $7 \mathrm{Ulog}_{10} \mathrm{CFUs} / \mathrm{g}$ of compost dry weight for the two windrows. In the case of step of maturation, the number of mesophilic bacteria did not varied remarkably and it fluctuated on average around $6 \mathrm{Ulog}_{10} \mathrm{CFU}$ s/g of compost dry weight.

On the other side, the number of thermophilic bacteria started to increase, from $4 \mathrm{Ulog}_{10} \mathrm{CFUs} / \mathrm{g}$ of compost dry weight, since the first weeks of pre-fermentation step, and it remained constant around $6 \mathrm{Ulog}_{10} \mathrm{CFUs} / \mathrm{g}$ of compost dry weight from the days 35 to 85 . At the end of this step of pre-fermentation, the number of thermophilic bacteria reached $4 \mathrm{Ulog}_{10} \mathrm{CFUs} / \mathrm{g}$ of compost dry weight for the two windrows. For the second step of maturation, the number of thermophilic bacteria showed low variation, particularly in the case of windrow W2, and a little increase is observed between 25-48 days of maturation (around $6 \mathrm{Ulog}_{10} \mathrm{CFUs} / \mathrm{g}$ of compost dry weight). For the number of spore-forming bacteria, the variation appeared very weak (around 4.5 Ulog $_{10}$ CFUs/g of compost dry weight) during the two steps of composting for the two windrows $\mathrm{W} 1$ and $\mathrm{W} 2$, and a little increase is always remarked specially during the 
Table 2. Heavy metal contents obtained during the two steps of composting and the metal concentration limits for composts in several countries.

\begin{tabular}{|c|c|c|c|c|c|c|c|c|c|c|c|}
\hline & & Step 1 of pre & fermentation & Step 2 of 1 & maturation & $\begin{array}{r}\text { Cana } \\
\text { mal }\end{array}$ & $\begin{array}{l}\text { n nor- } \\
\text { tion }\end{array}$ & $\begin{array}{l}\text { French nor- } \\
\text { malization }\end{array}$ & $\begin{array}{l}\text { German nor- } \\
\text { malization }\end{array}$ & $\begin{array}{l}\text { Spanish nor- } \\
\text { malization }\end{array}$ & $\begin{array}{l}\text { US nor- } \\
\text { malization }\end{array}$ \\
\hline & & $\begin{array}{l}\text { Initial waste } \\
\text { content }\end{array}$ & $\begin{array}{c}\text { Final waste } \\
\text { content }\end{array}$ & $\begin{array}{l}\text { Precompost } \\
\text { content }\end{array}$ & $\begin{array}{c}\text { Final compost } \\
\text { content }\end{array}$ & & & & imit values & & \\
\hline & & & & & & Class $A$ & Class B & & & & \\
\hline & & & & & $(\mathrm{mg} \mathrm{k}$ & -1 dry v & & & & & \\
\hline & $\mathrm{Cu}$ & $24,54 \pm 5,18$ & $42,83 \pm 7,37$ & $28,06 \pm 9,73$ & $43,25 \pm 2,66$ & 100 & 757 & 100 & 100 & 450 & 100 \\
\hline & $\mathrm{Cd}$ & $4,97 \pm 2,28$ & $1,75 \pm 0,50$ & $2,78 \pm 1,8$ & $3,6 \pm 1,5$ & 3 & 20 & 8 & 1,5 & 10 & 2 \\
\hline & $\mathrm{Cr}$ & $53,26 \pm 14,7$ & $24,15 \pm 5,76$ & $17,41 \pm 3,05$ & $26,68 \pm 1,44$ & 210 & 1060 & 100 & 100 & 400 & 100 \\
\hline & $\mathrm{Pb}$ & $90,47 \pm 27,80$ & $66,19 \pm 25,54$ & $80,01 \pm 56,94$ & $102,98 \pm 15,40$ & 150 & 500 & 800 & 150 & 300 & 150 \\
\hline & $\mathrm{Zn}$ & $195,60 \pm 20,30$ & $237,82 \pm 19,68$ & $160,30 \pm 30,65$ & $188,40 \pm 11,40$ & 500 & 1850 & 500 & 400 & 1100 & 400 \\
\hline & $\mathrm{Ni}$ & $64,34 \pm 20,30$ & $75,80 \pm 4,70$ & $37,47 \pm 11,50$ & $60,10 \pm 10,10$ & 62 & 180 & 200 & 50 & 120 & 50 \\
\hline & $\mathrm{Cu}$ & $42,32 \pm 9,60$ & $76,31 \pm 24,52$ & $71 \pm 12,54$ & $97,39 \pm 17,5$ & 100 & 757 & 100 & 100 & 450 & 100 \\
\hline & $\mathrm{Cd}$ & $4,80 \pm 2,78$ & $3,98 \pm 2,08$ & $3,04 \pm 2,08$ & $1,07 \pm 0,14$ & 3 & 20 & 8 & 1,5 & 10 & 2 \\
\hline & $\mathrm{Cr}$ & $30,15 \pm 7,98$ & $31,92 \pm 5,82$ & $26,73 \pm 11,69$ & $23,2 \pm 2,07$ & 210 & 1060 & 100 & 100 & 400 & 100 \\
\hline & $\mathrm{Pb}$ & $112,53 \pm 28,40$ & $82,20 \pm 17,42$ & $64,28 \pm 34,30$ & $92,16 \pm 27,75$ & 150 & 500 & 800 & 150 & 300 & 150 \\
\hline & $\mathrm{Zn}$ & $141,90 \pm 23,69$ & $191,29 \pm 32,12$ & $203,08 \pm 17,70$ & $229,15 \pm 36,50$ & 500 & 1850 & 500 & 100 & 1100 & 400 \\
\hline & $\mathrm{Ni}$ & $44,91 \pm 10,11$ & $62,85 \pm 16,56$ & $60,80 \pm 20,55$ & $74,0 \pm 5,10$ & 62 & 180 & 200 & 50 & 120 & 50 \\
\hline
\end{tabular}

Values for Class A of composts "which have no restrictions in use" and Class B of compost "which can be used on forest lands and road sides and for other landscaping purposes", according to Canadian normalization [19]; $n=3, \pm$ : Deviation standard.

days 34-35 and 25-48 of pre-fermentation and maturation steps, respectively (around $5 \mathrm{Ulog}_{10} \mathrm{CFUs} / \mathrm{g}$ of compost dry weight).

\subsubsection{Microbial DNA Concentration}

Microbial total DNA extracted from composting materials and followed during all the two steps of composting process showed a net variation over time, and revealed a good parallel increase with the temperature progress inside the waste materials (Figure 4). This increase varied between 13.2 to $26.1 \mu \mathrm{g}$ of total DNA per g dry weight. The lowest values of DNA are observed at the start and the end of each steps of process (around 13.2 $\mu \mathrm{g}$ of total DNA per g dry weight) and the highest values are always recorded during each thermophilic phase (around $26 \mu \mathrm{g}$ of total DNA per g dry weight). The determination of A260/A230 and A260/A280 ratios for compost DNA showed a significantly lower values (0.96 and 1.2) than those for DNA solutions of pure cultures (1.57 and 1.89).

\subsubsection{Microbial Diversity}

Changes in microbial diversity are assessed during the two steps of process by DNA extraction and polymerase chain reaction (PCR) of rRNA intergenic spacer. The RISA analysis of microbial communities change and diversity in compost showed an equivalent diversity at the start of the first step of composting process in the two windrows W1 and W2 (Figure 5, Lanes 1 and 2). During the thermophilic phases of the first step of process, there is a net variation in microbial diversity, this diversity appeared very rich and obvious in case of windrow W2 added with sewage sludge (Lanes 3 and 4). At the end of this first step of composting (Lanes 5 and 6), the RISA profile appeared equivalent. The start of the second step of composting showed a varied profile (Lanes 7 and 8) and diversity is richer also in case of windrow W2. The end of step of maturation exhibit a high microbial diversity materialized in the RISA profile by a various big number of bands (Lanes 9 and 10). Generally, this microbial diversity is much nuanced in the case of windrow W2 added with dry sewage sludge as compared to that observed in the case of windrow $\mathrm{W} 1$ free of sewage sludge. Also, it is important to mention that there were a temporal dynamics of the microbial communities with modifications of the RISA profile 


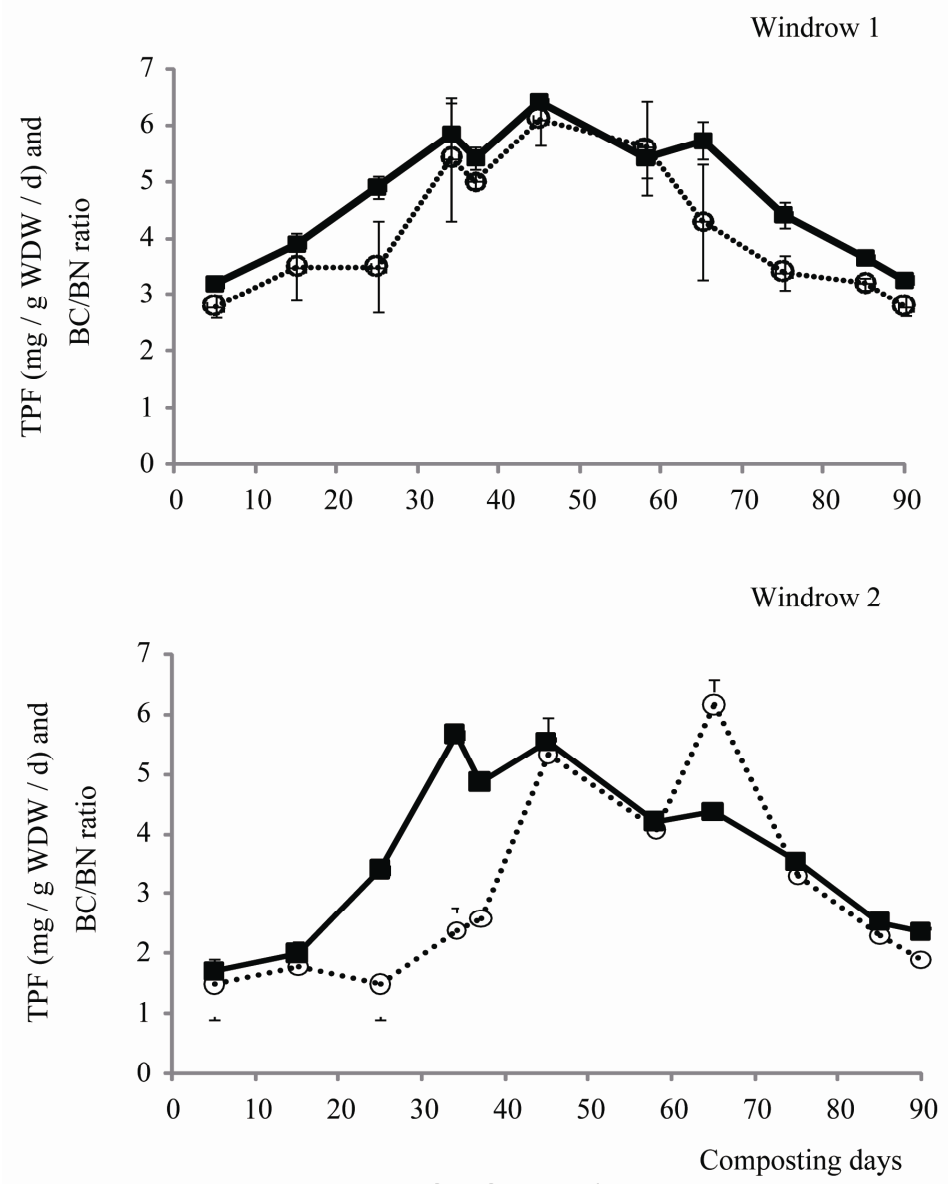

Step 1 of prefermentation
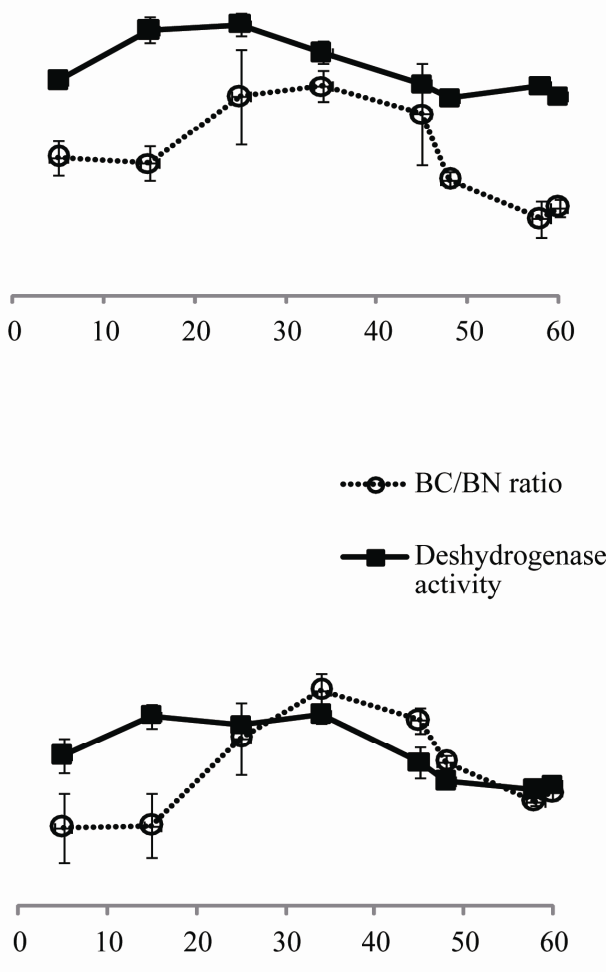

Step 2 of maturation

Figure 2. Progress of the deshydrogénase activity and $B_{C} / B_{N}$ ratio values in the two windrows during the two steps of composting.

over time of composting for the same type of composts.

unity structures as follow: Lane 1, Composting raw materials of W2; Lane 2, Composting raw materials of $\mathrm{W} 1$. Lane 3, Composting materials of W2 during thermophilic step; Lane 4, Composting materials of W1 during thermophilic step; Lane 5, Composting materials of W2 at the end of step of pre-fermentation; Lane 6, Composting materials of $\mathrm{W} 1$ at the end of step of pre-fermentation; Lane 7, Composting materials of W2 at the start of step of maturation; Lane 8, Composting materials of $\mathrm{W} 1$ at the start of step of maturation; Lane 9, Composting materials of W2 at the end of step of maturation; Lane 10, Composting materials of $\mathrm{W} 1$ at the end of step of maturation.

\subsection{Relationship between Some Selected Parameters of Composting}

A correlation matrix (Table 3) showed some significant relationships between the temperature, biomasses $\mathrm{C}$ and $\mathrm{N}$, deshydrogenase activity and DNA concentration. There was a good positive linear relationship between ambient temperature recorded inside the waste heap and deshydrogenase activity and $\mathrm{BC} / \mathrm{BN}$ ratio $(\mathrm{r}=0.93, \mathrm{r}=$ $0.96, r=0.87, r=0.71, P=0.01$, respectively). So, increase of temperature during each thermophilic phase is equivalent to a good deshydrogenase activity and a lot of active microbial biomass. Also, $\mathrm{BC} / \mathrm{BN}$ ratio is well correlated to the extracted DNA concentration only in the case of windrow $\mathrm{W} 2(\mathrm{r}=0.63, \mathrm{P}=0.01)$. The values of DNA concentration recorded in the case of windrow $\mathrm{W} 1$ is well correlated to those observed in case of windrow W2 ( $\mathrm{r}=0.61, \mathrm{P}=0.02)$. This result is valid for the two steps of composting, pre-fermentation and maturation. Moreover, stability of the temperature values inside the mass of waste means the stability of the microbial activity during the process (low deshydrogenase activity and $\mathrm{BC} / \mathrm{BN}$ ratio), and this fact could be exploited as an indicator of maturity of the compost.

\section{DISCUSSION AND CONCLUSIONS}

The present study investigates, in a semi-industrial pilot plant for compost production and under semi-arid 

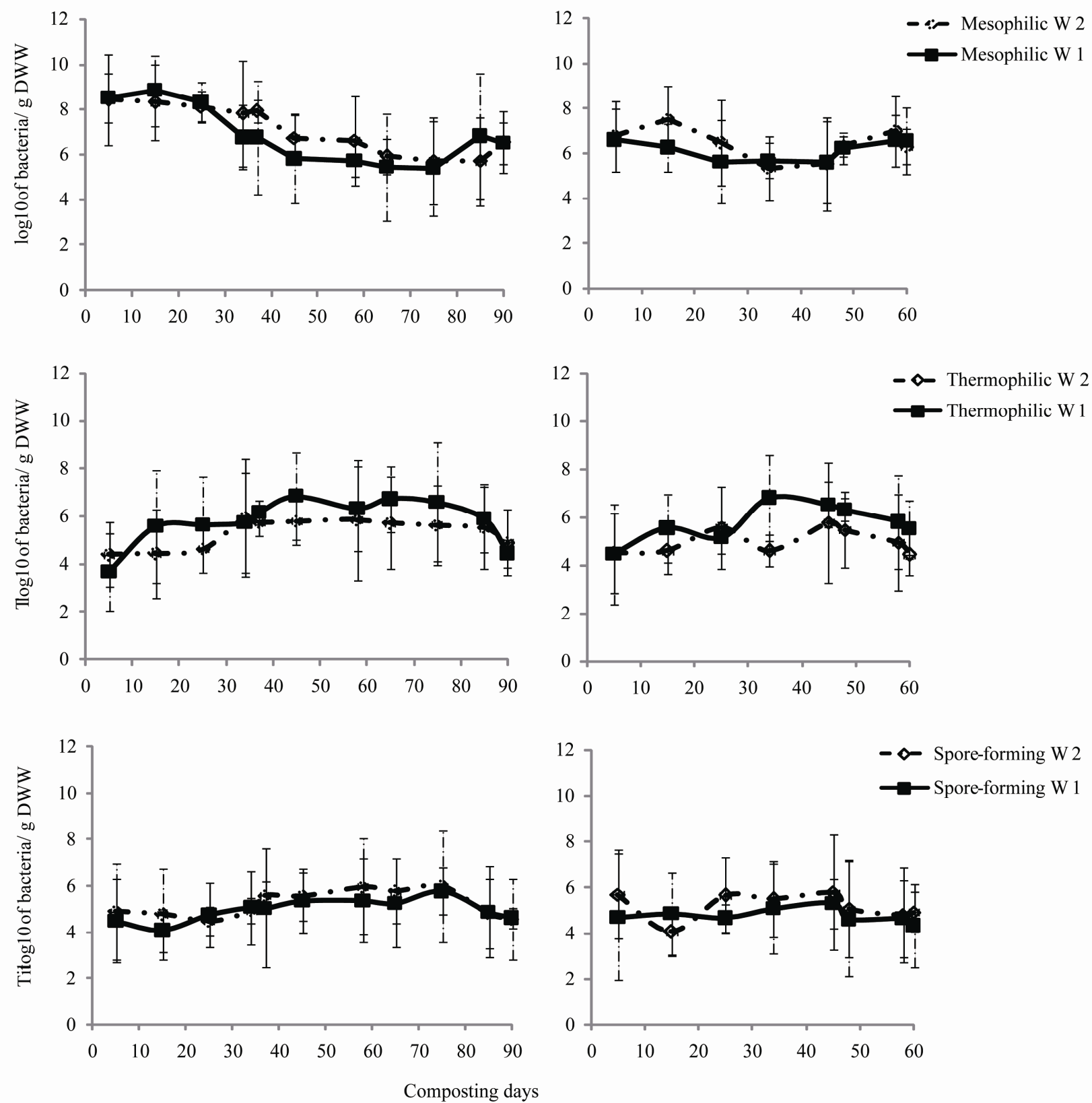

Step 1 of prefermentation
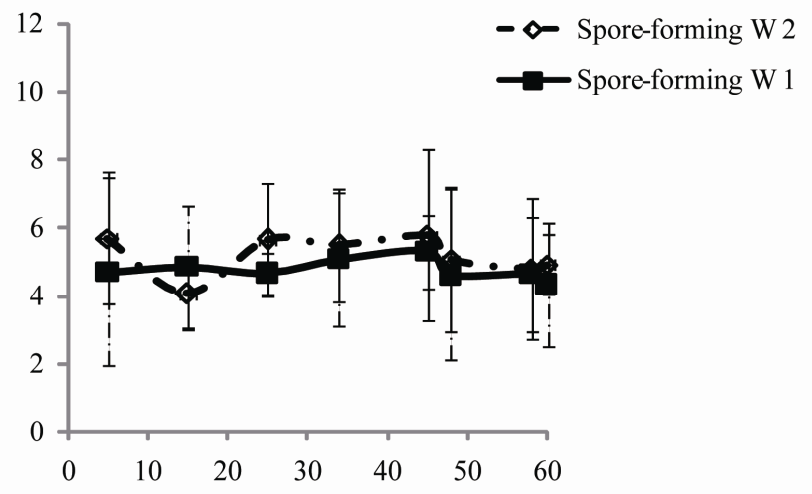

Step 2 of maturation

Figure 3. Progress of the number of mesophilic, thermophilic and spore-forming bacteria in the two windrows during the two steps of composting.

Tunisian pedo-climatic condition, a new and a simpleprocess of co-composting of municipal solid wastes and sewage sludge, and some physical-chemical and biological parameters are followed during two successive steps of pre-fermentation and of maturation using two types of pyramidal windrows W1 (100\% of municipal solid wastes) and W2 (60\% of municipal solid wastes and $40 \%$ of sewage sludge in weight). Results revealed that temperature profiles established during the two steps of composting in the two windrows W1 and W2 showed the three classical temperature steps of composting the mesophilic, thermophilic and cooling phases, respectively.

The optimal duration of pre-fermentation was evaluated to three months on average. Consequently, a maximum organic material recovery is ensured during a minimum time interval.

The second step of process of controlled fermentation 

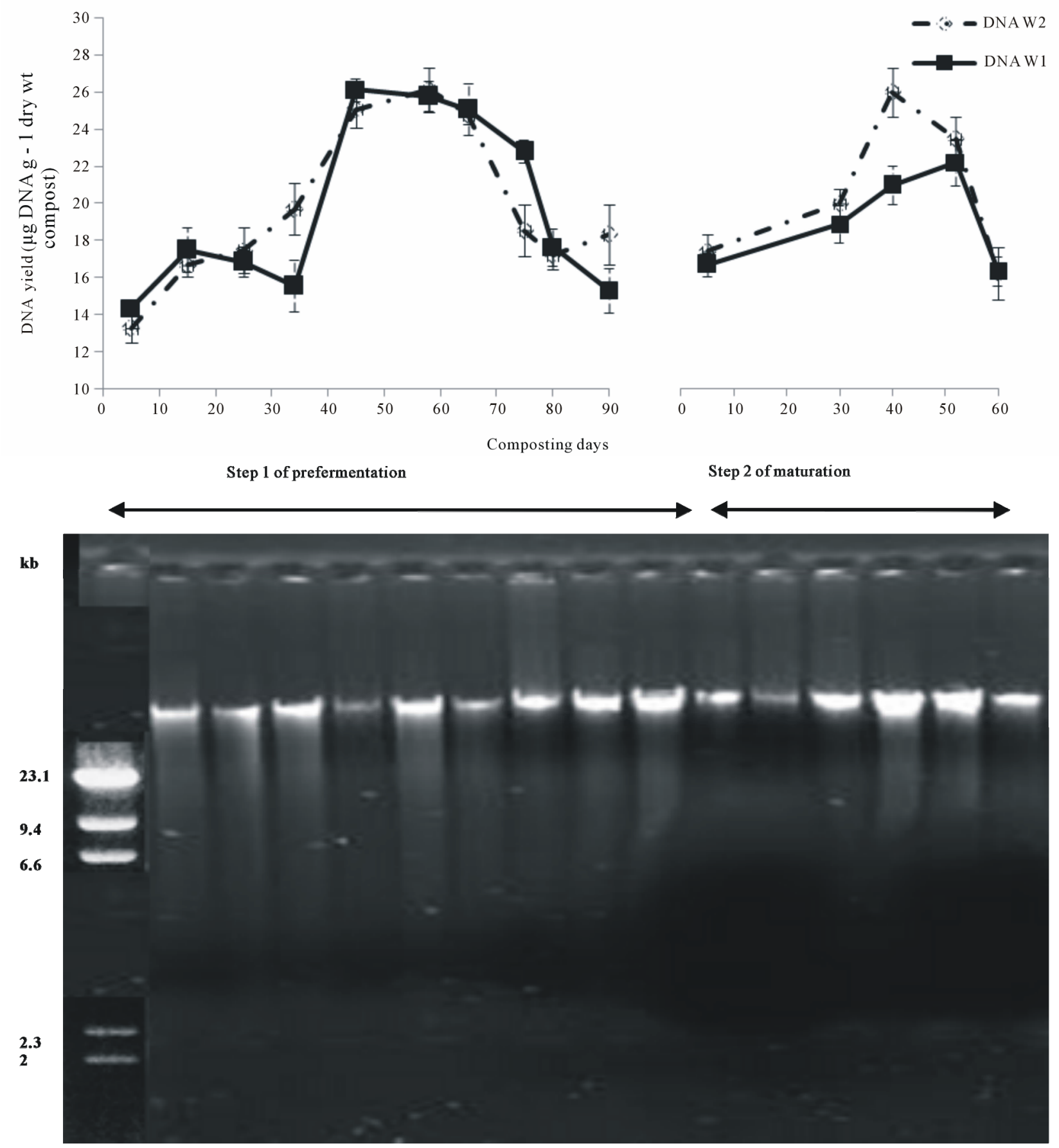

Figure 4. Progress of the total compost DNA concentrations and agarose gel electrophoresis of total DNA extracted from composting materials (W1) during the two steps of composting.

(step of maturation) is characterized by a degradation of the organic materials by microorganisms. The purpose of management of this second step of composting is to ensure favorable conditions in order to force the microbiological activity. The procedure of microbes during this second step of composting appeared on average less active than the one recorded during the first step of pre- fermentation. All parameters considered in the present study are in favour of this conclusion. We could explain this result by several factors mainly by the decrease or exhaustion and depletion of readly degradable compounds in the mass of waste materials.

This study confirm amongst others that temperature is the main parameter to consider in composting. This 


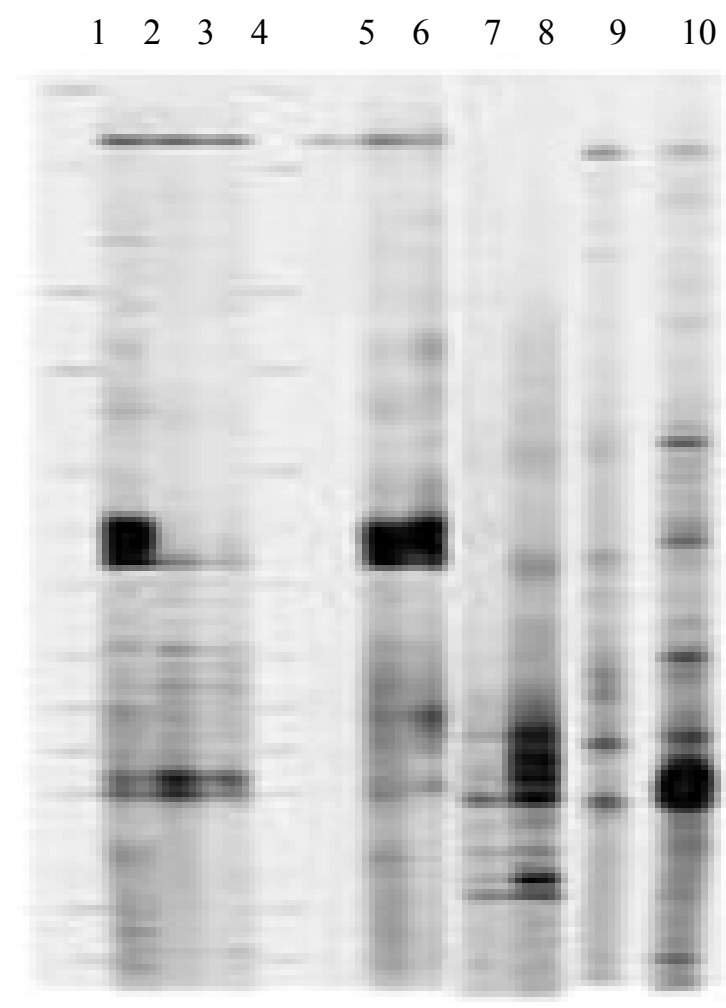

Figure 5. Example of the ARISA analysis of microbial communities change and diversity in compost of windrow 1.

important factor condition the funtionning of all the others parameters, specifically the microbial activity. As a result, the level of temperature condition and depends on the type of microorganisms operating during composting. So mesophilic microbes dominate at the beginning and at the end of each step of composting process; on the other hand, thermophilic microbes control the important step of composting, the thermophilic phase.

The values of temperature recorded during the two steps of composting revealed a good relashionship of this parameter with others studied here such as the deshydrogenase activity, the $\mathrm{B}_{\mathrm{C}} / \mathrm{B}_{\mathrm{N}}$ ratio and the total extracted DNA. In fact, statiscal analysis showed a good positive correlation of all these last parameters with temperature values recorded inisde the pile of waste. Also, the preliminaly molecular study using RISA method confirmed the high complexity of the microbial communauties acting during the two steps of composting in the two windrows W1 and W2 and underlined by several authors [20-23]. In addition, this preliminaly molecular study demonstrated a temporal dynamics of the microbial communities according to the modifications of the RISA profile over time of composting for the same type of composts. It appeared also from the result of this study that the microbial diversity is much nuanced in the case of windrow W2 added with sewage sludge as compared to that observed in the case of windrow W1 free of sewage sludge.

Furthermore, contaminants in feedstock can impact the quality, marketability, and use of finished composts. Overuse and persistence of some heavy metals, herbicides and insecticides could result in heavy metals and pesticide contamination of compost. The viability of composting depends very much on the quality and consistency of compost produced. Heavy metals content is of primary concern, and generally the values recorded during the two steps of composting are usually lower than the metal concentration limits imposed by several countries. So, it appeared from this study that the level of heavy metals contamination of the finished product of compost is satisfactory and suitable for soil application and enrichment. These low values of heavy metal content are related to many factors, mainly the low level of metal contaminants in feedstock used as raw composting materials in this plant as compared to those usually mentioned in several developed countries. This low level of heavy metal contaminants of the finished product is confirmed by the study of [18] in the same plant.

Compost is often contaminated by heavy metals due to inadequate separation of biodegradable fractions from non-degradable or inert materials. Composting can concentrate or dilute heavy metals present in waste material by adsorption and leaching, respectively. Lowering the amounts of heavy metal present depends on metal loss through leaching. The increase of metal level is due to weight loss in the course of composting following organic matter decomposition, release of carbon dioxide and water and mineralization processes [24,25]. As a consequence, potential utilisation of compost in agriculture might be restricted, and therefore, it is essential to monitor the magnitude of heavy metal contamination in soils, which urgently requires detailed chemical analysis of the soil.

Finally, this study reviews a new and simple composting process tested and used in a pilot plant for compost production under semi-arid Tunisian pedo-climatic condition, and some important chemical, physical and biological monitoring parameters are investigated in order to understand and to master the process of composting of municipal solid waste.

\section{ACKNOWLEDGMENTS}

This study was supported by the Japan International Cooperation Agency (JICA) within the framework of a research program. We thank the staff of a semi-industrial composting plant, Mr K. Ben Khedija and Ms Tounsi N. at ANPE, for their assistance, cooperation and participation in this study. We are most grateful to Pr H.W. Ackermann of 
Table 3. Pearson's correlation coefficients between the main parameters studied during the two steps of composting.

\begin{tabular}{|c|c|c|c|c|c|c|c|c|c|}
\hline & & $\mathrm{T}^{\circ} \mathrm{C} . \mathrm{W} 1$ & $\mathrm{~T}^{\circ} \mathrm{C} . \mathrm{W} 2$ & Deh. W1 & Deh. W2 & $\mathrm{BC} / \mathrm{BN} \mathrm{W} 1$ & $\mathrm{BC} / \mathrm{BN} \mathrm{W} 2$ & DNA W1 & DNA W2 \\
\hline \multirow[t]{3}{*}{ Temp. W1 } & $\mathrm{r}$ & 1.000 & $0.924 * *$ & $0.930 * *$ & $0.963 * *$ & $0.873^{* *}$ & $0.718^{* *}$ & 0.100 & $0.509^{*}$ \\
\hline & S & & 0.000 & 0.000 & 0.000 & 0.000 & 0.001 & 0.724 & 0.053 \\
\hline & Co & 96.053 & 112.217 & 11.136 & 8.969 & 11.247 & 9.394 & 0.996 & 4.416 \\
\hline \multirow[t]{3}{*}{ Temp. W2 } & $\mathrm{r}$ & & 1.000 & $0.999 * *$ & $0.938 * *$ & $0.862 * *$ & $0.593 * *$ & 0.008 & 0.494 \\
\hline & $\mathrm{S}$ & & . & 0.000 & 0.000 & 0.000 & 0.007 & 0.977 & 0.061 \\
\hline & $\mathrm{Co}$ & & 153.619 & 15.116 & 11.042 & 14.035 & 9.818 & 0,098 & 5.267 \\
\hline \multirow[t]{3}{*}{ Dehy. W1 } & $\mathrm{r}$ & & & 1.000 & $0.943 * *$ & $0.875^{* *}$ & $0.593 * *$ & 0.003 & 0.480 \\
\hline & S & & & & 0.000 & 0.000 & 0.007 & 0.992 & 0.070 \\
\hline & Co & & & 1.492 & 1.095 & 1.404 & 0.967 & 0,003 & 0.503 \\
\hline \multirow[t]{3}{*}{ Dehy. W2 } & $\mathrm{r}$ & & & & 1.000 & $0.830 * *$ & $0.639 * *$ & 0.047 & 0.503 \\
\hline & S & & & & & 0.000 & 0.003 & 0.867 & 0.056 \\
\hline & $\mathrm{Co}$ & & & & 0.903 & 1.036 & 0.811 & 0,046 & 0.427 \\
\hline \multirow[t]{3}{*}{$\mathrm{BC} / \mathrm{BN} \mathrm{W} 1$} & $\mathrm{r}$ & & & & & 1.000 & $0.638^{* *}$ & 0.080 & 0.424 \\
\hline & S & & & & & & 0.003 & 0.776 & 0.115 \\
\hline & $\mathrm{Co}$ & & & & & 1.727 & 1.120 & 0,098 & 0.450 \\
\hline \multirow[t]{3}{*}{ BC/B W2 } & $\mathrm{r}$ & & & & & & 1.000 & 0.472 & $0.711 * *$ \\
\hline & S & & & & & & & 0.076 & 0.003 \\
\hline & $\mathrm{Co}$ & & & & & & 1.782 & 0.640 & 0.837 \\
\hline \multirow[t]{3}{*}{ DNA W1 } & $\mathrm{r}$ & & & & & & & 1.000 & $0.610^{*}$ \\
\hline & S & & & & & & & & 0.016 \\
\hline & $\mathrm{Co}$ & & & & & & & 0.907 & 0.480 \\
\hline \multirow[t]{3}{*}{ DNA W2 } & $\mathrm{r}$ & & & & & & & & 1.000 \\
\hline & $\mathrm{S}$ & & & & & & & & \\
\hline & $\mathrm{Co}$ & & & & & & & & 0.683 \\
\hline
\end{tabular}

** Correlation is significant at level 0.01 (bilateral). * Correlation is significant level at 0.05 (bilateral). r: Pearson correlation, Co : Covariance, S: Sig. (bilateral), Microbial $\mathrm{C}$ biomass $\left(\mathrm{B}_{\mathrm{C}}\right)$, Microbial $\mathrm{N}$ biomass $\left(\mathrm{B}_{\mathrm{N}}\right)$, DNA: DNA concentration, Deh: Deshydrogenase activity, W1 and W2 : Windrows 1 and 2.

the Department of Microbiology, Faculty of Medicine, Laval University in Quebec, Canada, for helpful discussion and critical review of the manuscript.

\section{REFERENCES}

[1] Ouatmane, A., Provenzano, M.R., Hafidi, M. and Senesi N. (2000). Compost maturity assessment using calorimetry, spectroscopy and chemical analysis. Compost Science \& Utilization, 8, 124-134.

[2] de Bertoldi, M., Vallini, G. and Pera, A. (1985) Practices Composting of agricultural wastes and other wastes. In: Gasser, J. K. R. (Ed.).

[3] Hassen, A., Belguith, K., Jedidi, N., Cherif, A., Cherif, M. and Boudabous, A. (2001) Microbial characterization during composting of municipal solid waste. Bioresource
Technology, 80, 185-192. doi:10.1016/S0960-8524(01)00065-7

[4] Whittle, A.J. and Dyson, A.J. (2002) The fate of heavy metals in green waste composting. The Environmentalist, 22, 13-21.

doi:10.1007/BF00505887

[5] Ranjard, L., Poly, F., Combrisson, J., Gourbiere, F., Richaume, A., Thioulouse, J. and Nazaret, S. (2000) Heterogeneous cell density and genetic structure of bacterial pools associated with various soil microenvironments as determined by enumeration and DNA fingerprinting approach (RISA). Microbial Ecology, 39, 263272.

[6] Seishi, I., David, M.C.L., Roberts, W.K.N. and Ytow, N. (2004) Microbial community analyses using a simple, rapid detection method for DNA fingerprints with a fluorescence scanner. Journal of Bioscience and Bioen- 
gineering, 98, 500-503.

[7] Lehtokari, M., Nikkola, P. and Paatero, J. (1983) Determination of ATP from compost using the firefly bioluminescence technique. European Journal of Applied Microbiology and Biotechnology, 17, 187-192.

doi:10.1007/BF00505887

[8] Hiraishi, A., Iwasaki, M., and Shinjo, H. (2000) Terminal restriction pattern analysis of $16 \mathrm{~S}$ rRNA genes for the characterization of bacterial communities of activated sludge. Journal of Bioscience and Bioengineering, 90, 148-156.

[9] Czaczyk, K., Trojanowska, K., Stachowiak, B. and Dubisz, H. (2001) Changes in Cell Number and the ATP Content during the Composting Process. Polish Journal of Environmental Studies, 10, 149-153.

[10] Gillet, R. (1986). Industrial treatment of urban and assimilated wastes. Organization and management of a service. Management treaty of solid wastes and its application to under developed countries. WHO Regional Office for Europe, Copenhagen, 2, 538.

[11] Bremmer, J.M. and Mulvaney, C.S. (1982) Total nitrogen. In: Methods of Soil Analysis. Part 2. Chemical and Microbiological Properties, Ed., C. A. Bluck. American Society of Agronomy, Madison, WI, 1179-1239.

[12] Nelson, D.W. and Sommers, L.E. (1982) Total carbon, organic carbon, and organic matter. In: Methods of Soil Analysis. Part 2. Agronomy Monographs, Eds. A. L. Page et al. American Society of Agronomy, Madison, WI, 539-579.

[13] Hassen, A., Jedidi, N., Cherif, M., M'Hiri, A., Boudabous, A. and Cleemput, O.V. (1998) Mineralization of nitrogen in a clayey loamy-soil amended with organic wastes enriched with $\mathrm{Zn}, \mathrm{Cu}$ and $\mathrm{Cd}$. Bioresource Technology, 64, 39-45. doi:10.1016/S0960-8524(97)00153-3

[14] Tabatabai, M.A. (1982) Soil enzymes. Agronomy, 9, 903-947.

[15] Bouzaiane, O., Cherif, H., Saidi, N., Jedidi, N. and Hassen, A. (2007) Effects of municipal solid waste compost application on the microbial biomass of cultivated and non-cultivated soil in a semi-arid zone. Waste Management \& Research, 25, 334-342. doi: $10.1177 / 0734242$ X07078287

[16] Leckie, S.E., Prescott, C.E., Grayston, S.J., Neufeld, J.D. and Mohn, W.W. (2004) Comparison of chloroform fumigation-extraction, phospholipid fatty acid, and DNA methods to determine microbial biomass in forest humus. Soil Biology and Biochemistry, 36, 529-532. doi:10.1016/j.soilbio.2003.10.014

[17] Steffan, R.J., Goksoyr, J., Bej, A.K. and Atlas, R.M. (1988) Recovery of DNA from soils and sediments. Applied and Environmental Microbiology, 54, 2908-2915.

[18] Ben, A.L., Hassen, A., Jedidi, N., Saidi, N., Bouzaiane, O. and Murano, M. (2006) Microbial C and N dynamics during composting process of urban solid waste. Waste Management \& Research, 25, 24-29.

[19] CCME: Canadian Council of Ministers of the Environment, 1995. Proposed compost standards for Canada, 1993. Cited in the Composting Council of Canada, Composting Technologies and Practices.

[20] Mustin, M. (1987) Le compost "gestion de la matière organique". Editions François Dubusc- Paris, 954.

[21] Pedro, M.S., Haruta, S., Hazaka, M., Shimada, R., Yoshida, C., Hiura, K., Ishii, M. and Igarashi, Y. (2001) Denaturing gradient gel electrophoresis analyses of microbial community from field-scale composter. Journal of Bioscience and Bioengineering, 91, 159-165. doi:10.1263/ibb.91.159

[22] Marshall, M.N., Cocolin, L., Mills, D.A. and VanderGheynst, J.S. (2003) Evaluation of PCR primers for denaturing gradient gel electrophoresis analysis of fungal communities in compost. Journal of Applied Microbiology, 95, 934-948. doi:10.1046/j.1365-2672.2003.02062.x

[23] Poulsen, P.H.B., Møller, J. and Magid, J. (2008) Determination of a relationship between chitinase activity and microbial diversity in chitin amended compost. Bioresource Technology, 99, 4355-4359. doi:10.1016/j.biortech.2007.08.042

[24] Wagner, D.J., Bacon, G.D., Knocke, W.R. and Switzenbaum, M.S. (1990) Changes and variability in concentration of heavy metals in sewage sludge during composting. Environmental Technology, 11, 949-960. doi:10.1080/09593339009384947

[25] Canaruttto, S., Petruzzelli, G., Lubrano, L. and Guidi, G.V. (1991) How composting affects heavy metal content. BioCycle, 32, 48-50. 